\title{
The Effect of Doctor Competence, Interpersonal Communication and Work Satisfaction on the Effectiveness of the Internship Program in Jambi Province
}

\author{
Yosi Rulianto ${ }^{1}$, Mukhtar $^{1}$, Risnita $^{1}$, Muhamad Taridi $^{2 *}$ \\ ${ }^{1}$ School of Postgraduate of State Islamic University of Sulthan Thaha Saifuddin Jambi- Indonesia \\ ${ }^{2}$ State Islamic University of Sulthan Thaha Saifuddin Jambi - Indonesia
}

DOI: $10.36348 /$ SJHSS.2019.v04i12.001 $\quad$ | Received: 02.12.2019| Accepted: 09.12.2019| Published: 17.12 .2019

*Corresponding author: Muhamad Taridi

\section{Abstract}

The aim of this study was to test the hypothesis of the doctor competence influence, interpersonal communication, and job satisfaction on the effectiveness of internship programs at the General Hospital in Jambi Province. This research applied a quantitative research with survey method. The sampling technique used probability sampling with a sample of 90 interns. Hypothesis testing used path analysis with significance level $a=0.05$. The findings of this study indicated that there were influences both partially and simultaneously: 1). doctor's competence $\left(\mathrm{X}_{1}\right)$ on the effectiveness of the internship program $\left(X_{4}\right)$. 2). interpersonal communication $\left(X_{2}\right)$ on the effectiveness of internal programs $\left(X_{4}\right)$. 3). job satisfaction $\left(\mathrm{X}_{3}\right)$ on the effectiveness of internal programs $\left(\mathrm{X}_{4}\right)$. 4). doctor competence $\left(\mathrm{X}_{1}\right)$, interpersonal communication $\left(\mathrm{X}_{2}\right)$, and job satisfaction $\left(\mathrm{X}_{3}\right)$ on the effectiveness of internal programs $\left(\mathrm{X}_{4}\right)$. The implication of this study was the competence of the measured intern's doctor and the factors that influenced it. Factors affecting the performance of interns physicians were gender, intelligence level, graduation time, internship placement, duration of internship, perception of internal living benefits, internal bureaucratic system, internal briefing, internship acceptance, acceptance by the public and ranks in the vehicle, facilities, adaptation, workload, number and type of cases, leave entitlements, Faculty of Medicine curriculum, perception of medical knowledge, public health efforts, role of accompanying physicians, interest in becoming doctors at Puskesmas (Public Health Center), discipline, communication, and choice of actions.

Keywords: Doctor competence, interpersonal communication, job satisfaction, effectiveness of internal programs.

Copyright @ 2019: This is an open-access article distributed under the terms of the Creative Commons Attribution license which permits unrestricted use, distribution, and reproduction in any medium for non-commercial use (NonCommercial, or CC-BY-NC) provided the original author and source are credited.

\section{INTRODUCTION}

The doctor's internship program is an integrated internship program as a process of transition from a medical student to a professional who will later practice a doctor independently. Interns program is an integrated, comprehensive, and independent internship program that is required for all graduates of medical faculties in Indonesia and graduates of overseas medical faculties who have undertaken adaptation programs aimed at the acquisition, independence and alignment of educational and practical results in the field so that in the future doctors who have carried out more competent internship programs.

Referring to the survey results and conclusions of the Health Research and Development Agency assessment of the Indonesian Ministry of Health it turns out that the Indonesian Doctors Internship Program has run well in a number of available rides and is equally beneficial for both participants and Internship rides. A minimum target of 400 cases. Generally the companion is considered to have good competence [1].

But apparently there are still many things that must be addressed from the Indonesian Internship Education Program both from internship management, improvement of manuals and log books, as well as the completeness of facilities in the internship vehicle. Internship program is still needed, but it is considered necessary to make old adjustments in its implementation. There is no real support from the Regional Government, it can be seen from the existence of several hospitals and Public Health Center that have not met the requirements as a vehicle for internship. Internship participants generally face obstacles in the limited facilities and diagnostic facilities, diagnostic support, and other supporting facilities for internship. As well as a misperception regarding the status of internship which is still considered co-ass, honorariums 
which are considered to be insufficient and often come late due to lack of regular management internship.

The internship program is considered very useful because it can distribute doctors in health care facilities that do not have human resources. One of them is at the health public center which is the spearhead of primary health care in Indonesia before patients are referred to the hospital [2].

From the results of interviews conducted by researchers at one of the accompanying physicians at the Olak Kemang Public Health Center, Jambi City, in February 2019, the accompanying doctor considered that the proportion of interns' doctor's performance varied considerably, which was very good, good and bad [3]. Therefore, it is necessary to measure the effect of doctor competence, interpersonal communication, and job satisfaction on the effectiveness of internal programs in Jambi Province. This research was conducted by cross sectional method on interns and accompanying physicians. By knowing these factors, it is expected that the implementation of the internship program can be improved in order to improve the quality of doctors and services.

\section{LITERATURE REVIEW}

Gibson in Pasalong said that effectiveness is the achievement of goals from joint efforts the degree of achievement indicates the degree of effectiveness [4]. Tjokroamidjojo in Pasalong (said that effectiveness is the implementation of administration to achieve more results as planned, achieve the goals to be achieved and more empowered results [4]. While Keban in Pasalong [5] says that an organization can be said to be effective if the goals of the organization or values as set in the vision are achieved [4].

Robbins in Tika provides a definition of effectiveness as the level of organizational achievement in the short and long term [6]. The point is effectiveness is a measurement standard to describe the level of success of an organization in achieving predetermined goals.

The internship program is a phase of medical practice training where medical graduates can renew their competencies that have been achieved by going directly to the community to apply their medical knowledge with supervision. After completing an internship program for approximately 1-3 years, interns will receive an SIP and STR that can be used to carry out medical practice in full. The Indonesian Doctors Internship Program (PIDI) is a professional training process based on primary service competency preregistration in order to update the competencies that have been achieved after obtaining qualifications as doctors through basic medical education. In Indonesia, PIDI is carried out by the Indonesian Doctors Internship Committee (KIDI) at the central and provincial levels.
The PIDI implementation time is one year which is divided into a hospital and community health center.

The main objective of the internship program is to integrate the medical knowledge received by medical student graduates during their college studies with clinical work in hospitals or clinics by consolidating what they have learned and helping them develop and improve the clinical skills they need to practice medicine, and serve patients in a safe and satisfying way [7]

Based on exposure to the theory of effectiveness and internship programs, it can be concluded that the effectiveness of internship programs in this study is a standard of achievement to describe the level of success in integrating medical knowledge received by graduates of medical students during their tertiary studies with clinical work in hospitals or clinics. By consolidating what they have learned and assisting them in developing and improving the clinical skills they need to practice medicine, and serving patients in a safe and satisfying way.

Based on the Law of the Republic of Indonesia Number 29 Year 2004 regarding Medical Practices, the understanding of doctors and dentists is doctors, specialist doctors, dentists and dental specialists graduating medical or dental education both domestically and abroad that are recognized by the Government of the Republic of Indonesia in accordance with statutory regulations [8].

Doctors who have just completed competencybased medical education who will carry out medical practice and / or will undergo specialist doctor programs as participants in the doctor's internship program. The doctor graduates follow the preregistration training program called the doctor interns program which is a phase of understanding and alignment of what has been obtained during medical education with practice in the field [9].

Activities of Indonesian Doctors Internship Program Participants, among others, conduct primary health services with a family medicine approach to patients in a professional manner that includes medical cases, surgical cases, emergencies, psychiatric conditions in children, adults and old age, in families and in society holistically, integrated and plenary. In addition, conducting consultations and referrals, medical and non-medical scientific activities and health programs as an effort to improve public health [10].

According to the Department of Continuous Medical Education of Dubai's Ministry of Health [11], the duties of interns participants include, all interned doctors are expected to follow all $\mathrm{MOH}$ rules and regulations as long as they are part of the internship program and take part in morning reports from their 
department assigned, taking part in morning rounds and discussing medical cases in the department. In addition interns physicians are required to fill all logbooks with daily documentation according to the requirements and each interns physician must be under the direct supervision of a senior staff doctor who works in every action to the patient so that if there is a difficulty he can immediately consult. Interns are expected to avoid matters or actions taken to patients without the knowledge and purpose of the accompanying doctor or senior doctor which includes meetings, treatment, repatriation and invasive actions. After completing the internship program, the interns' physician must provide a request for the internship certificate to the intern's supervisor. If a form of violation of the above points is found, it will be the basis for terminating this internship program.

Based on the description of the theory, it can be concluded that the competence of doctors in research is the ability possessed by a graduate of medical education based on science, skills, and also a professional attitude to be able to practice. The indicators of doctor competency in accordance with the Indonesian Doctors Internship Implementation Handbook have seven competencies, namely: a) effective communication, b) clinical skills, c) medical foundation of doctors, d) management of health problems, e) information management, f) selfawareness and self-development, and g) ethics, morals, medico legal, and professional.

Uchjana Effendy gave the definition of interpersonal communication (interpersonal communication) is communication between the communicator and a communicant. This type of communication is considered to be the most effective in efforts to change attitudes, opinions, and behavior of a person because it is dialogical in nature, in the form of conversation and has a direct flow / feedback [12]. Arni Muhammad quoted Wenburg's opinion that interpersonal communication is the process of exchanging information between two people who can be directly identified. Some other terms of interpersonal communication are dyadic communication, dialogue, interview, conversation, and face-to-face communication [13].

Based on the study of concepts that have been described previously, it can be synthesized that meant interpersonal communication in this research is the process of exchanging information that occurs between doctors with other individuals in the organization so that reciprocal relationships occur as one of the bases for the success of an organization. As for the indicators of interpersonal communication are: (1) convey information clearly; (2) receiving and giving feedback; (3) environmental conditions; and (4) dealing with emotional interactions. Indicators of interpersonal communication variables are measured on a Likert scale.

Blum said that job satisfaction is a general attitude which is the result of a special attitude towards work scores, self-adjustment and social relations of individuals. According to Stephen $\mathrm{P}$ Robbins, satisfaction is a positive feeling a person (customer) about one's work which is the result of an evaluation of its characteristics and after comparing between the performance or the results felt (services received and felt) with the expected [14]. Satisfaction is an assessment of a person about the extent to which his work as a whole satisfies his needs or general attitude which is the result of some special attitudes towards work factors, adjustment and social relations of individuals outside of work [15].

Coulquitt, Le Pine, and Wesson argue that job satisfaction is defined as a pleasurable state resulting from the appraisal of one's job or job experiences (job satisfaction is defined as a pleasant emotional state that results from one's judgment or work experience) [16] In line with the above opinion, According to Wagner and Hollenbeck, satisfaction is a pleasurable feeling that results from the perception that one's job is full or allows for the fulfillment of one's important job values. Our definition of job satisfaction includes three key components: values, importance of values, and perception [16] (job satisfaction is a pleasant feeling that results from perceptions that fulfill one's work or the possibility to fulfill one's important work values, job satisfaction includes three main components: values, the importance of values, and perceptions). Dissatisfaction in performance needs to be managed, with the hope that it will not be sustainable.

Based on the description of various opinions and theories that have been presented, it can be concluded that job satisfaction in this study is a response that is a feeling of pleasure or displeasure towards the actual work individually as an outcome of the evaluation of work that is influenced by worker factors, relations between colleagues, and the value that provides benefits to the individual within a certain period. The dimensions and indicators of employee job satisfaction are as follows: (1) the job itself with responsibilities, interests and personal development, work variations, autonomy at work (2) Income or compensation with indicators of the adequacy of salary payments, benefits and salaries, accuracy payroll salaries, allowances and honorarium, and lethargy between expected and reality paid (3) supervision with indicators of clarity of duties, responsibilities, and guidance from supervisors, (4) promotion with indicators with promotional policy indicators, transparency of promotion opportunities, and levels of promotion. Career, and (5) coworkers with indicators of social compatibility, mutual respect and mutual assistance at work. 


\section{MATERIAL AND METHODS}

This research uses a quantitative approach. The method used is descriptive survey method. Cresswell explained that the survey research method in which researchers conducted a survey of a sample or the entire population of people to describe the attitudes, behavior, opinions, or characteristics of the population by sampling data from one population using a questionnaire as a primary data collection tool [17]. The population in this study were intern's doctors in Jambi Province. Jambi Province is geographically composed of 9 districts and 2 municipalities. Not all Cities / Regencies have implemented an internship program from the Ministry of Health Office. In Jambi Province there are only 7 districts and 1 city that carry out internships. The total population of regencies and cities that carry out the internships program is 120 people (each regency and city consists of 15 interns). Considering the total population of the study was 120 people, the researchers used a total sampling technique, where all populations were sampled. Of the 120 people,
30 were used as trial samples, and 90 as research samples

The instrument in this study used a questionnaire, and documentation. Data analysis used descriptive analysis and inferential analysis and the results were generalized (referenced) for the population where the sample was taken [18]. Inferential analysis using statistical formulas (competency test and regression analysis). Before the hypothesis is tested first, the analysis requirements test is done by means of a normality test and a homogeneity test.

\section{RESULTS}

a. Research Data Description

This section presents descriptive analysis results (mean, median, mode, and standard deviation) internal variable effectiveness data $\left(\mathrm{X}_{4}\right)$ and doctor competency variable data $\left(\mathrm{X}_{1}\right)$, interpersonal communication variable data $\left(\mathrm{X}_{2}\right)$ and job satisfaction variable data $\left(\mathrm{X}_{3}\right)$. Complete data summary scores for each variable can be seen in Table-1 below.

Table-1: The Data of Summary Results of Four Variables

\begin{tabular}{|c|c|c|c|c|c|}
\hline & $\begin{array}{l}\text { (X1) doctor } \\
\text { competence influence }\end{array}$ & $\begin{array}{l}\text { (X2) Interpersonal } \\
\text { communication }\end{array}$ & $\begin{array}{l}\text { (X3) Work } \\
\text { satisfaction }\end{array}$ & $\begin{array}{l}\text { (X4) Program } \\
\text { Effectiveness }\end{array}$ \\
\hline \multirow[t]{2}{*}{$\mathrm{N}$} & Valid & 90 & 90 & 90 & 90 \\
\hline & Missing & 0 & 0 & 0 & 0 \\
\hline \multicolumn{2}{|c|}{ Mean } & 148.92 & 145.03 & 137.86 & 146.79 \\
\hline \multicolumn{2}{|c|}{ Median } & 149.00 & 145.00 & 138.00 & 147.00 \\
\hline \multicolumn{2}{|c|}{ Mode } & 149.00 & 145 & 138 & 147 \\
\hline \multicolumn{2}{|c|}{$\begin{array}{l}\text { Std. } \\
\text { Deviation }\end{array}$} & 5.906 & 8.49 & 6.19 & 6.21 \\
\hline \multicolumn{2}{|c|}{ Range } & 34 & 46 & 33 & 34 \\
\hline \multicolumn{2}{|c|}{ Minimum } & 132 & 121 & 121 & 130 \\
\hline \multicolumn{2}{|c|}{ Maximum } & 166 & 167 & 154 & 164 \\
\hline \multicolumn{2}{|c|}{ Sum } & 13403 & 13053 & 12407 & 13211 \\
\hline
\end{tabular}

b. Testing Requirements Analysis.

Normality testing is carried out on all groups, the results are normal, homogeneity testing on all groups produces homogeny, and linearity testing on all groups produces Linear.

\section{c. Hypothesis testing}

The First Hypothesis: There is a direct effect of Doctor Competence $\left(X_{1}\right)$ on the Effectiveness of the Internship Program $\left(\mathbf{X}_{4}\right)$.
Based on the value of $t$ counted (5.56)> $t$ table (1.969), so $\mathrm{H}_{0}$ is rejected and $\mathrm{H}_{1}$ is accepted. This means that the research hypothesis which states Doctor Competency $\left(\mathrm{X}_{1}\right)$ has a direct effect on the effectiveness of the Internship Program $\left(\mathrm{X}_{4}\right)$ can be accepted because it has been tested for its truth. Manually calculation gets the same number as the calculation using SPSS ver. 22.0 can be seen in the following Table-2:

Table-2: Coefficients ${ }^{\text {a }}$

\begin{tabular}{|c|c|c|c|c|c|c|}
\hline \multirow{2}{*}{\multicolumn{2}{|c|}{ Model }} & \multicolumn{2}{|c|}{ Unstandardized Coefficients } & \multirow{2}{*}{$\begin{array}{l}\text { Standardized Coefficients } \\
\text { Beta }\end{array}$} & \multirow[t]{2}{*}{$\mathbf{t}$} & \multirow[t]{2}{*}{ Sig. } \\
\hline & & B & Std. Error & & & \\
\hline \multirow[t]{2}{*}{1} & (Constant) & 117.646 & 16.865 & & 6.976 & .000 \\
\hline & $\left(\mathrm{X}_{1}\right)$ Doctor Competence & .196 & .113 & .52 & 1.729 & .087 \\
\hline
\end{tabular}

Table-2 Results of Path Analysis between Doctor Competency variables $\left(\mathrm{X}_{1}\right)$ and Effectiveness of Internship Programs $\left(X_{4}\right)$. In Table-2 the results of $\rho 41$ $=0.52[19]$, both the results of calculations both manually and using the help of the SPSS program, show the same path coefficient value $\rho 41=0.52$. Based on the results of the calculation of the influence of Doctor Competence $\left(\mathrm{X}_{1}\right)$ on the Effectiveness of the Internship 
Program $\left(\mathrm{X}_{4}\right)$ of $29.07 \%$, while the remaining $70.93 \%$ is influenced by other variables.

The Second Hypothesis: There is a direct effect of Interpersonal Communication (X2) on the Effectiveness of the Internship Program (X4).

Based on the value of $\mathrm{t}$ count $(3.17)>\mathrm{t}$ table (1.969), so $\mathrm{H}_{0}$ is rejected and $\mathrm{H}_{1}$ is accepted. This means that the research hypothesis stating Interpersonal
Communication $\left(\mathrm{X}_{2}\right)$ has a direct effect on the effectiveness of the Internship Program $\left(\mathrm{X}_{4}\right)$ can be accepted because it is tested for its truth. Manual calculations get the same number as calculations using SPSS ver.22.0 can be seen in the following Table-3:

Table-3 Results of Path Analysis between Interpersonal Communication $\left(\mathrm{X}_{2}\right)$ and Effectiveness of Internship Programs $\left(\mathrm{X}_{4}\right)$.

Table-3: Coefficients ${ }^{\text {a }}$

\begin{tabular}{|c|c|c|c|c|c|c|}
\hline \multirow{2}{*}{\multicolumn{2}{|c|}{ Model }} & \multicolumn{2}{|c|}{$\begin{array}{l}\text { Unstandardized } \\
\text { Coefficients }\end{array}$} & \multirow{2}{*}{$\begin{array}{l}\text { Standardized } \\
\text { Coefficients } \\
\text { Beta } \\
\end{array}$} & \multirow[t]{2}{*}{$\mathbf{t}$} & \multirow[t]{2}{*}{ Sig. } \\
\hline & & B & Std. Error & & & \\
\hline \multirow[t]{2}{*}{1} & (Constant) & 113.207 & 10.730 & & 10.550 & .000 \\
\hline & $\begin{array}{l}\left(\mathrm{X}_{2}\right) \text { Interpersonal } \\
\text { Communication }\end{array}$ & .232 & .074 & .610 & 3.17 & .002 \\
\hline
\end{tabular}

In Table- 3 the results of $\rho 42=0.61$ [20], both calculation results manually or using the SPSS program, show the same path coefficient value $\rho 42=0.61$. Based on the results of calculations, the magnitude of the influence of Interpersonal Communication $\left(\mathrm{X}_{2}\right)$ on the Effectiveness of the Internship Program $\left(\mathrm{X}_{4}\right)$ was $36.85 \%$, while the remaining $63.15 \%$ was influenced by other variables.

The Third Hypothesis: There is a direct influence of Doctor Competence (X1) and Interpersonal Communication (X2) on the Effectiveness of the Internship Program (X4).
Based on the value of $\mathrm{F}$ count $(61)>\mathrm{F}_{\text {table }}$ (3.45), so $\mathrm{H}_{0}$ is rejected and $\mathrm{H}_{1}$ is accepted. This means that the research hypothesis that states Doctor Competence $\left(\mathrm{X}_{1}\right)$ and Interpersonal Communication $\left(\mathrm{X}_{2}\right)$ on the Effectiveness of the Internship Program $\left(\mathrm{X}_{4}\right)$ is acceptable because it has been tested for its truth. Manual calculations get the same number as calculations using SPSS ver.22.0 can be seen in the following Table-4:

Table-4 Results of Path Analysis between Doctor Competency variables $\left(\mathrm{X}_{1}\right)$ and Interpersonal Communication $\left(\mathrm{X}_{2}\right)$ on the Effectiveness of Internship Programs $\left(\mathrm{X}_{4}\right)$.

Table-4: Model of Summary ${ }^{b}$

\begin{tabular}{|l|l|l|l|l|}
\hline Model & R & R Square & Adjusted R Square & Std. Error of the Estimate \\
\hline 1 & .61 & .3721 & .088 & 6.090 \\
\hline a. Predictors: (Constant), (X2) Interpersonal communication, \\
(X1) Doctor Competence \\
\hline
\end{tabular}

Table-5: ANOVA ${ }^{\mathrm{a}}$

\begin{tabular}{|c|c|c|c|c|c|c|}
\hline \multicolumn{2}{|c|}{ Model } & Sum of Squares & df & Mean Square & $\mathbf{F}$ & Sig. \\
\hline \multirow[t]{3}{*}{1} & Regression & 390.693 & 2 & 195.347 & 61 & $.007^{\mathrm{b}}$ \\
\hline & Residual & 3226.295 & 87 & 37.084 & & \\
\hline & Total & 3616.989 & 89 & & & \\
\hline \multicolumn{7}{|c|}{ a. Dependent Variable: (X4) Effectiveness of Program } \\
\hline \multicolumn{7}{|c|}{$\begin{array}{l}\text { b. Predictors: (Constant), ), (X2) Interpersonal communication, } \\
\text { (X1) Doctor Competence }\end{array}$} \\
\hline
\end{tabular}

Based on the output summary table listed in Table-4, it can be seen the coefficient of determination of 0.3721 . While the simultaneous influence between Doctor Competency variables $\left(\mathrm{X}_{1}\right)$ and Interpersonal Communication $\left(\mathrm{X}_{2}\right)$ together on the Internship Program Effectiveness $\left(\mathrm{X}_{4}\right)$ variable is seen from the value of $R 24.12$ ( $R_{\text {Square }}$ ) of $=0.3721$. The influence of other variables outside the model on the effectiveness of the Internship Program Effectiveness $\left(\mathrm{X}_{4}\right)$ is $\varepsilon 2=1$ $\mathrm{R} 24.12=1-0.3721=0.6279(62.79 \%)$.

Based on the two calculations of the multiple correlation coefficient above, the Doctor Competency variable $\left(\mathrm{X}_{1}\right)$ and Interpersonal Communication $\left(\mathrm{X}_{2}\right)$ together affect the Effectiveness of the Internship Program $\left(\mathrm{X}_{4}\right)$ of $62.79 \%$ while the remaining $37.21 \%$ is influenced by other variables. 
The Fourth Hypothesis: There is a direct effect of Doctor Competence $\left(\mathrm{x}_{1}\right)$ on Job Satisfaction $\left(\mathbf{X}_{3}\right)$

Based on the value of $t$ count $(2.16)>t$ table (1.969), so $\mathrm{H}_{0}$ is rejected and $\mathrm{H}_{1}$ is accepted. This means that the research hypothesis stating Doctor Competence $\left(\mathrm{X}_{1}\right)$ has a direct effect on Job Satisfaction $\left(\mathrm{X}_{3}\right)$ can be accepted because it is tested for its truth.
Manually calculation gets the same number as the calculation using SPSS ver.22.0 can be seen in the following Table-5:

Table-5 Results of Path Analysis between Doctor Competency variables $\left(\mathrm{X}_{1}\right)$ and Job Satisfaction $\left(\mathrm{X}_{3}\right)$.

Table-6: Coefficients ${ }^{\text {a }}$

\begin{tabular}{|l|l|l|l|l|l|l|}
\hline \multirow{2}{*}{ Model } & Unstandardized Coefficients & Standardized Coefficients & t & \multirow{2}{*}{ Sig. } \\
\cline { 3 - 5 } \multicolumn{2}{|l|}{1} & B & Std. Error & Beta & & \\
\cline { 2 - 5 } & $($ Constant $)$ & 92.236 & 16.320 & & 5.652 & .000 \\
\hline & $(\mathrm{x} 1)$ Doctor competence & .306 & .110 & .14 & 2.16 & .006 \\
\hline
\end{tabular}

In Table- 6 the results of $\rho 31=0.14$ [20], both the results of calculations both manually and using the help of the SPSS program, show the same path coefficient value $\rho 31=0.14$. Based on the results of calculations, the magnitude of the influence of Doctor Competence $\left(\mathrm{X}_{1}\right)$ on Job Satisfaction $\left(\mathrm{X}_{3}\right)$ is $40.13 \%$, while the remaining $59.87 \%$ is influenced by other variables.

The Fifth Hypothesis: There is a direct influence on Interpersonal Communication Style $\left(\mathbf{X}_{2}\right)$ on Job Satisfaction $\left(\mathbf{X}_{3}\right)$
Based on the value of $t$ count (11.15) $>t$ table (1.969), so $\mathrm{H}_{0}$ is accepted and $\mathrm{H}_{1}$ is rejected. This means that the research hypothesis that states Interpersonal Communication $\left(\mathrm{X}_{2}\right)$ directly affects Job Satisfaction $\left(\mathrm{X}_{3}\right)$ is accepted because its truth is tested. Manually calculation gets the same number as the calculation using SPSS ver.22.0 can be seen in the following table 4.60:

Table-7 Results of Path Analysis between Interpersonal Communication $\left(\mathrm{X}_{2}\right)$ and Job Satisfaction $\left(\mathrm{X}_{3}\right)$ variables.

Table-7: Coefficients ${ }^{\text {a }}$

\begin{tabular}{|c|c|c|c|c|c|c|}
\hline \multirow{2}{*}{\multicolumn{2}{|c|}{ Model }} & \multicolumn{2}{|c|}{$\begin{array}{l}\text { Unstandardized } \\
\text { Coefficients }\end{array}$} & \multirow{2}{*}{$\begin{array}{l}\text { Standardized } \\
\text { Coefficients } \\
\text { Beta }\end{array}$} & \multirow[t]{2}{*}{$\mathbf{t}$} & \multirow[t]{2}{*}{ Sig. } \\
\hline & & B & Std. Error & & & \\
\hline \multirow[t]{2}{*}{1} & (Constant) & 142.104 & 11.226 & & 12.658 & .000 \\
\hline & $\begin{array}{l}\text { (X2) Interpersonal } \\
\text { Communication }\end{array}$ & -.029 & .077 & .500 & 11.15 & .706 \\
\hline
\end{tabular}

In Table-7 the results of $\rho 32=0.50$ [20], both the results of calculations both manually and using the help of the SPSS program, show the same path coefficient value $\rho 32=0.50$. Based on the results of calculations, the magnitude of the influence of Interpersonal Communication $\left(\mathrm{X}_{2}\right)$ on Job Satisfaction $\left(\mathrm{X}_{3}\right)$ of $27.17 \%$, while the remaining $72.83 \%$ is influenced by other variables.

The Sixth Hypothesis: There is a direct influence of Doctor Competence $\left(X_{1}\right)$ and Interpersonal Communication $\left(\mathbf{X}_{2}\right)$ on Job Satisfaction $\left(\mathbf{X}_{3}\right)$
Based on the value of $\mathrm{F}$ count $(24.58)>\mathrm{F}$ table (3.45), so $\mathrm{H}_{0}$ is rejected and $\mathrm{H}_{1}$ is accepted. This means that the research hypothesis that states Doctor Competence $\left(\mathrm{X}_{1}\right)$ and Interpersonal Communication $\left(\mathrm{X}_{2}\right)$ influences Job Satisfaction $\left(\mathrm{X}_{3}\right)$ can be accepted because it is tested for its truth. Manual calculations get the same number as calculations using SPSS ver.22.0 can be seen in the following Table-7:

Table-9 Results of Path Analysis between Doctor Competency variables $\left(\mathrm{X}_{1}\right)$ and Interpersonal Communication $\left(\mathrm{X}_{2}\right)$ on Job Satisfaction $\left(\mathrm{X}_{3}\right)$

Table-8: Model Summary ${ }^{\text {b }}$

\begin{tabular}{|l|l|l|l|l|}
\hline Model & R & R Square & Adjusted R Square & Std. Error of the Estimate \\
\hline 1 & .52 & .2704 & .080 & 6.074 \\
\hline \multicolumn{2}{|l|}{ a. Predictors: (Constant), (X2) Interpersonal communication, (X1) Doctor competence } \\
\hline \multicolumn{2}{|l}{ b. Dependent Variable: (X3) Work Satisfaction } \\
\hline
\end{tabular}


Table-9: ANOVA ${ }^{\text {a }}$

\begin{tabular}{|l|l|l|l|l|l|l|}
\hline \multicolumn{2}{|l|}{ Model } & Sum of Squares & df & Mean Square & F & Sig. \\
\hline \multirow{3}{*}{1} & Regression & 226.455 & 2 & 113.228 & 24.58 & $.032^{\mathrm{b}}$ \\
\cline { 2 - 7 } & Residual & 2753.945 & 87 & 31.655 & & \\
\cline { 2 - 7 } & Total & 2980.400 & 89 & & & \\
\hline
\end{tabular}

Based on the output summary table listed in Table- 8 , it can be seen the coefficient of determination of 0.2704 . While the simultaneous influence between the variable Doctor Competence $\left(\mathrm{X}_{1}\right)$ and Interpersonal Communication $\left(\mathrm{X}_{2}\right)$ together on the Job Satisfaction variable $\left(\mathrm{X}_{3}\right)$ seen from the value of $\mathrm{R} 23.12(\mathrm{R}$ Square $)$ of $=0.2704$. The influence of other variables outside the model on the Job Satisfaction variable $\left(\mathrm{X}_{3}\right)$ is $\varepsilon 2=1$ $\mathrm{R} 23.12=1-0.2704=0.7296$

Based on the two path coefficient calculations, Doctor Competency $\left(\mathrm{X}_{1}\right)$ and Interpersonal Communication $\left(\mathrm{X}_{2}\right)$ variables together affect Job Satisfaction $\left(\mathrm{X}_{3}\right)$ of $72.96 \%$ while the remaining $27.04 \%$ is influenced by other variables.
The Seventh Hypothesis: There is a direct effect on Job Satisfaction $\left(X_{3}\right)$ on the Effectiveness of the Internship Program $\left(\mathbf{X}_{4}\right)$

Based on the value of $t$ count $(6.34)>t$ table (1.696), so $\mathrm{H}_{0}$ is rejected and $\mathrm{H}_{1}$ is accepted. This means that the research hypothesis which states Job Satisfaction $\left(\mathrm{X}_{3}\right)$ has a direct effect on the effectiveness of the Internship Program $\left(\mathrm{X}_{4}\right)$ can be accepted because it has been tested for its truth. Manual calculations get the same number as calculations using SPSS ver.22.0 can be seen in the following Table-8:

Table-10 Results of Path Analysis between Organizational Culture variables $\left(\mathrm{X}_{3}\right)$ and Internship Program Effectiveness $\left(\mathrm{X}_{4}\right)$.

Table-10: Coefficients ${ }^{\text {a }}$

\begin{tabular}{|l|l|l|l|l|l|l|}
\hline \multirow{2}{*}{ Model } & Unstandardized Coefficients & Standardized Coefficients & \multirow{2}{*}{ t } & \multirow{2}{*}{ Sig. } \\
\cline { 3 - 6 } \multicolumn{2}{|l|}{1} & B & Std. Error & Beta & & \\
\hline & $($ Constant $)$ & 134.760 & 14.758 & & 9.132 & .000 \\
\cline { 2 - 5 } & $\left(\mathrm{X}_{3}\right)$ work satisfaction & .087 & .107 & .56 & 6.34 & .417 \\
\hline \multicolumn{2}{|l|}{ a. Dependent Variable: $\left(\mathrm{X}_{3}\right)$ Effectiveness program } & & \\
\hline
\end{tabular}

In Table-10 the results of $\rho 43=0.56$ [20], both the results of calculations manually or using the SPSS program, show the same path coefficient value $\rho 43=$ 0.56. Based on the results of calculations, the magnitude of the effect of Job Satisfaction (X3) on the Effectiveness of the Internship Program (X4) of 96\%, while the remaining $4 \%$ is influenced by other variables.

The Eighth Hypothesis: There is a direct influence on Doctor Competency $\left(\mathbf{X}_{1}\right)$, Interpersonal Communication $\left(X_{2}\right)$ and Job Satisfaction $\left(X_{3}\right)$ on the Effectiveness of Internship Programs $\left(\mathbf{X}_{4}\right)$

Based on the value of $F$ count (59.28)> $F$ table (3.45), so $\mathrm{H}_{0}$ is rejected and $\mathrm{H}_{1}$ is accepted. This means that the research hypothesis which states that there is a direct influence of Doctor Competence $\left(\mathrm{X}_{1}\right)$ Interpersonal Communication $\left(\mathrm{X}_{2}\right)$ and Job Satisfaction $\left(\mathrm{X}_{3}\right)$ on the Effectiveness of the Internship Program $\left(\mathrm{X}_{4}\right)$ can be accepted because it has been tested for its truth. Manual calculations get the same number as calculations using SPSS ver.22 can be seen in the following table 9:

Table-9 Results of Path Analysis between Doctor Competency variables $\left(\mathrm{X}_{1}\right)$ Interpersonal Communication $\left(\mathrm{X}_{2}\right)$ and Job Satisfaction $\left(\mathrm{X}_{3}\right)$ on the Effectiveness of Internship Programs $\left(\mathrm{X}_{4}\right)$.

\begin{tabular}{|l|l|l|l|l|}
\hline \multicolumn{5}{|c|}{ Model Summary $^{\mathbf{b}}$} \\
\hline Model & R & R Square & Adjusted R Square & Std. Error of the Estimate \\
\hline 1 & .5927 & .3513 & .083 & 6.105 \\
\hline a. Predictors: (Constant), (X3) work satisfaction, (X2) Interpersonal communication (X1) doctor competence \\
\hline b. Dependent Variable: (X4) Effectiveness Program \\
\hline
\end{tabular}


Yosi Rulianto et al.; Saudi J. Humanities Soc Sci, Dec. 2019; 4(12): 751-761

\begin{tabular}{|c|c|c|c|c|c|c|c|c|c|}
\hline \multicolumn{9}{|c|}{ ANOVA $^{a}$} & \\
\hline \multicolumn{2}{|c|}{ Model } & \multicolumn{2}{|c|}{ Sum of Squares } & \multirow{2}{*}{$\begin{array}{l}\text { df } \\
3\end{array}$} & \multicolumn{2}{|c|}{ Mean Square } & $\mathbf{F}$ & Sig. & \\
\hline \multirow[t]{3}{*}{1} & Regression & \multicolumn{2}{|c|}{411.647} & & \multicolumn{2}{|c|}{137.216} & 59.28 & $.015^{b}$ & \\
\hline & Residual & \multicolumn{2}{|l|}{3205.342} & 86 & \multicolumn{2}{|l|}{37.271} & & & \\
\hline & Total & \multicolumn{2}{|c|}{3616.989} & 89 & & & & & \\
\hline \multicolumn{9}{|c|}{ a. Dependent Variable: (X4) Effectiveness Program } & \\
\hline \multicolumn{10}{|c|}{ b. Predictors: (Constant), (X3) work satisfaction (X2) Interpersonal cor } \\
\hline \multicolumn{10}{|c|}{ Coefficients $^{\text {a }}$} \\
\hline \multirow{2}{*}{\multicolumn{3}{|c|}{ Model }} & \multicolumn{3}{|c|}{ Unstandardized Coefficients } & \multirow{2}{*}{\multicolumn{2}{|c|}{$\frac{\text { Standardized Coefficients }}{\text { Beta }}$}} & \multirow[t]{2}{*}{$\mathbf{t}$} & \multirow[t]{2}{*}{ Sig. } \\
\hline & & & $\mathbf{B}$ & & Std. Error & & & & \\
\hline \multirow[t]{4}{*}{1} & \multicolumn{2}{|c|}{ (Constant) } & 93.445 & \multicolumn{2}{|c|}{20.465} & & 4.566 & .000 \\
\hline & \multicolumn{2}{|c|}{ (X1) doctor competence } & .070 & \multicolumn{2}{|c|}{.121} & .065 & & .576 & .566 \\
\hline & \multicolumn{2}{|c|}{ (X2) Interpersonal communication } & .219 & \multicolumn{2}{|c|}{.079} & .300 & & 2.780 & .007 \\
\hline & \multicolumn{2}{|c|}{ (X3)work satisfaction } & .081 & \multicolumn{2}{|c|}{.108} & .080 & & .750 & .455 \\
\hline
\end{tabular}

Based on the output summary table listed in Table-9, it can be seen the coefficient of determination of 0.5927 . While the simultaneous influence between the variable Doctor Competence $\left(\mathrm{X}_{1}\right)$ and Interpersonal Communication $\left(\mathrm{X}_{2}\right)$ and job satisfaction $\left(\mathrm{X}_{3}\right)$ together on the variable effectiveness of the Internship Program $\left(\mathrm{X}_{4}\right)$ seen from the value of $\mathrm{R} 24,321$ ( $\mathrm{R}$ square $)$ of = 0.3513 . The influence of other variables outside the model on the Job Satisfaction variable (X3) is $\varepsilon 2=1$ $\mathrm{R} 24,321=1-0.3513=0.6487$.

Based on the two path coefficient calculations above, Doctor Competency $\left(\mathrm{X}_{1}\right)$ and Interpersonal Communication $\left(\mathrm{X}_{2}\right)$ and job satisfaction $\left(\mathrm{X}_{3}\right)$ variables together affect the Effectiveness of the Internship Program $\left(\mathrm{X}_{4}\right)$ of $64.87 \%$ while the remaining $35.13 \%$ is influenced by another variable.

The results of the calculation of each track studied, namely the direct and indirect influence between Doctor Competence $\left(\mathrm{X}_{1}\right)$ on Job Satisfaction $\left(\mathrm{X}_{3}\right)$, the influence of Interpersonal Communication $\left(\mathrm{X}_{2}\right)$ on Job Satisfaction $\left(\mathrm{X}_{3}\right)$, the relationship between Doctor Competence $\left(\mathrm{X}_{1}\right)$ and Interpersonal Communication $\left(\mathrm{X}_{2}\right)$ and Doctor Competency $\left(\mathrm{X}_{1}\right)$ and Interpersonal Communication $\left(\mathrm{X}_{2}\right)$ together on Job Satisfaction $\left(\mathrm{X}_{3}\right)$ and the influence of other variables outside of the overall research obtained the following results.

The Ninth Hypothesis: There is an influence of Doctor Competence $\left(X_{1}\right)$ on the Effectiveness of the Internship Program $\left(X_{4}\right)$ through Job Satisfaction $\left(\mathbf{X}_{3}\right)$

Based on the value of $t$ count $(1.198)>t$ table (1.969), so $\mathrm{H}_{0}$ is rejected and $\mathrm{H}_{1}$ is accepted. This means that the research hypothesis which states that there is an influence of Doctor Competence $\left(\mathrm{X}_{1}\right)$ on the Effectiveness of the Internship Program $\left(\mathrm{X}_{4}\right)$ through Job Satisfaction $\left(\mathrm{X}_{3}\right)$ can be accepted because it is tested for its truth.

The coefficient of determination is 0.016 . While the simultaneous influence of the Doctor
Competency variable $\left(\mathrm{X}_{1}\right)$ and Job Satisfaction $\left(\mathrm{X}_{3}\right)$ together on the Internship Program Effectiveness variable $\left(\mathrm{X}_{4}\right)$ seen from the value of $\mathrm{R} 241.3(\mathrm{R}$ Square $)$ of $=0.016$ The influence of other variables outside the model on the Job Satisfaction variable (X3) is $\varepsilon 2=1$ $\mathrm{R} 241.3=1-0.016=0.984$.

Based on the two path coefficient calculations, the Doctor Competency variable $\left(\mathrm{X}_{1}\right)$ to the Effectiveness of the Internship Program $\left(\mathrm{X}_{4}\right)$ through Job Satisfaction $\left(\mathrm{X}_{3}\right)$ is $98.4 \%$ while the remaining $1.6 \%$ is influenced by other variables.

The Tenth Hypothesis: There is the influence of Interpersonal Communication $\left(X_{2}\right)$ on the Effectiveness of the Internship Program $\left(\mathbf{X}_{4}\right)$ through Job Satisfaction (X3)

Based on the value of $t$ count $(4.77)>t$ table (1.969), so H0 is rejected and H1 is accepted. This means that the research hypothesis which states that there is an influence of Interpersonal Communication $\left(\mathrm{X}_{2}\right)$ on the Effectiveness of the Internship Program $\left(\mathrm{X}_{4}\right)$ through Job Satisfaction $\left(\mathrm{X}_{3}\right)$ can be accepted because it is tested for its truth.

The coefficient of determination is 0.207 while the simultaneous effect of the Interpersonal Communication $\left(\mathrm{X}_{2}\right)$ variables together on the Internship Program Effectiveness $\left(\mathrm{X}_{4}\right)$ variable is seen from the $R 24.32\left(R_{\text {Square }}\right.$ ) value of $=0.207$. The effect of other variables outside the model on the Job Satisfaction variable $\left(\mathrm{X}_{3}\right)$ is $\varepsilon 2=1-\mathrm{R} 24.32=1-0.207=$ 0.793 .

Based on the two path coefficient calculations above, the Interpersonal Communication variable $\left(\mathrm{X}_{2}\right)$ on the Effectiveness of the Internship Program $\left(\mathrm{X}_{4}\right)$ through Job Satisfaction $\left(\mathrm{X}_{3}\right)$ was $79.3 \%$ while the remaining $20.7 \%$ was influenced by other variables.

\section{DISCUSSION}

The direct effect of Doctor Competency $\left(\mathrm{X}_{1}\right)$ on the Effectiveness of the Internship Program $\left(\mathrm{X}_{4}\right)$ 
Listening to the results of the processed data through path analysis, it can be explained that the high competence of doctors has an effect on the effectiveness of the Internship Program. In other words, based on the results of this study it is proven that the effectiveness of the Internship Program can be influenced by the competence of doctors. Doctor competence influences the effectiveness of the internet program. The increasing competence of doctors, tends to increase the effectiveness of the Internship Program.

Direct Effect of Interpersonal Communication $\left(\mathrm{X}_{2}\right)$ on the Effectiveness of the Internship Program $\left(\mathrm{X}_{4}\right)$.

Based on the analysis, the analysis provides evidence that interpersonal communication has a significant influence on the effectiveness of international programs. This means that leader behavior is one of the important factors that can affect job satisfaction. A close relationship and mutual help with coworkers and with leaders is very important and has a strong relationship with job satisfaction, the better the leader in managing his employees the more comfortable and satisfied the employees are in doing their work, and vice versa. So this supports the research of Miller et al., [21], and Elisabeth A. Sorentino [22], Durrotun Nafisah [23] and Ramlan Rivandi [24] regarding the positive relationship of Interpersonal Communication with job satisfaction.

The direct effect of Doctor Competence $\left(\mathrm{X}_{1}\right)$ and Interpersonal Communication $\left(\mathrm{X}_{2}\right)$ on the Effectiveness of the Internship Program $\left(\mathrm{X}_{4}\right)$

People who have knowledge and believers according to Al-maraghi will get a special place in the sight of Allah SWT, they will get the reward of reward and good pleasure multiplied. People who have knowledge will be given the ability to think and act to respond to life in this world, so they find convenience and solutions to the problems of life they face. The better the education of a nation, the better the quality of that nation that is a general assumption of a nation's education program. The reality of life has also proven that the quality of education has an influence on the quality of life.

\section{Effect of Doctor Competency $\left(\mathrm{X}_{1}\right)$ on interpersonal communication $\left(\mathrm{X}_{3}\right)$}

Indonesian Medical Council as a regulator of the medical profession that was born in accordance with the mandate of Law No. 29 of 2004 concerning Medical Practices, among others, has the duty and authority to ratify the Professional Education Standards and Competency Standards of Indonesian Doctors. Following global and local developments, this standard is regularly reviewed and revised in required sections. The Book of Professional Education Standards and Doctor Competency Standards is a strengthening and development in accordance with the advancement of medical science and technology and as an effort to answer the community's need for quality assurance of medical education as the earliest part of achieving patient safety in the implementation of medical practice.

The direct effect of Interpersonal Communication $\left(\mathrm{X}_{2}\right)$ on job satisfaction $\left(\mathrm{X}_{3}\right)$

The importance of interpersonal communication takes place dialogically which shows the occurrence of interaction, someone who is involved in this form of communication has a dual function, each of which becomes the speaker and listener alternately. In the process of dialogic communication, it appears that there is an effort from the communication actors for a mutual change and empathy. From this process, mutual respect arises not because of social status, but is based on the assumption that each is a human being who is entitled and obliged, appropriate and reasonable to be respected and respected as human beings.

In order for interpersonal communication to produce effective interpersonal relationships and cooperation can be improved, we need to be open, trusting, supportive, and open that encourages attitudes that best understand, respect, and develop mutual quality. Interpersonal relationships need to be developed and improved by improving relations and cooperation between various parties.

Direct influence of Doctor Competence $\left(\mathrm{X}_{1}\right)$ and Interpersonal Communication $\left(\mathrm{X}_{2}\right)$ on Job Satisfaction $\left(\mathrm{X}_{3}\right)$

Based on the research findings in accordance with the theory put forward by Raph White and Ronald Lippitt which states that Interpersonal Communication is a style used by a leader to be able to manage power and can influence his subordinates. According to researchers based on the results of the analysis that each interpersonal communication has an effect on the continuity of the way to communicate.

The direct effect of job satisfaction $\left(\mathrm{X}_{3}\right)$ on the Effectiveness of the Internship Program $\left(\mathrm{X}_{4}\right)$

Okki Diasmoro's research results show that there is a significant positive relationship between interpersonal communication and job satisfaction. The higher the interpersonal communication, the higher the job satisfaction of the early adult employees of PT. Gangsar Tulungagung. The influence of interpersonal communication on job satisfaction by $16.5 \%(r=0.406$; $\mathrm{p}=0.000<0.01 ;=0.165$ ).

Effect of Doctor Competence $\left(\mathrm{X}_{1}\right)$ on the Effectiveness of Internship Programs $\left(\mathrm{X}_{4}\right)$ ) through Job Satisfaction $\left(\mathrm{X}_{3}\right)$

Based on the existing criteria, it turns out that the value of $\mathrm{t}$ count $(1.198)>\mathrm{t}$ table (1.99), so that $\mathrm{H} 0$ is rejected and $\mathrm{H} 1$ is accepted. This means that the research hypothesis which states that there is an influence of Doctor Competence $\left(\mathrm{X}_{1}\right)$ on the Effectiveness of the Internship Program $\left(\mathrm{X}_{4}\right)$ through 
job satisfaction $\left(\mathrm{X}_{3}\right)$ is acceptable because it has been tested for its truth.

Effect of Interpersonal Communication $\left(\mathrm{X}_{2}\right)$ on the Effectiveness of Internship Programs $\left(\mathrm{X}_{4}\right)$ through job satisfaction $\left(\mathrm{X}_{3}\right)$

Based on the existing criteria, it turns out that the $t_{\text {coun }} \mathrm{t}(4.77)>t_{\text {table }}(1.99)$, so that $\mathrm{H} 0$ is rejected and $\mathrm{H} 1$ is accepted. This means that the research hypothesis which states that there is an influence of Interpersonal Communication $\left(\mathrm{X}_{2}\right)$ on the Effectiveness of the Internship Program $\left(\mathrm{X}_{4}\right)$ through job satisfaction $\left(\mathrm{X}_{3}\right)$ can be accepted because it is tested for its truth.

The direct influence of Doctor Competence $\left(\mathrm{X}_{1}\right)$, Interpersonal Communication $\left(\mathrm{X}_{2}\right)$ and Job Satisfaction $\left(\mathrm{X}_{3}\right)$ on the Effectiveness of Internship Programs $\left(\mathrm{X}_{4}\right)$

The results of the multiple correlation coefficient analysis on hypothesis ten provide information that each of them is not only partially capable of influencing the Effectiveness of the Internship Program, but simultaneously all three are able to exert a significant influence on the Effectiveness of the Internship Program. This gives an understanding that being a doctor is not easy, there are many things that influence it, not only the competence of the doctor but also must be supported by strong interpersonal communication, even more importantly supported by good job satisfaction.

\section{CONCLUSION}

Based on the analysis of data processing and discussion that has been presented in the previous chapter. So the conclusions drawn in this study are as follows:

1. There is a direct influence on the competence of doctors $\left(\mathrm{X}_{1}\right)$ on the effectiveness of internal programs $\left(\mathrm{X}_{4}\right)$. It means that the competence of doctors has a significant influence on the effectiveness of the internship program.

2. There is a direct effect of interpersonal communication $\left(\mathrm{X}_{2}\right)$ on the effectiveness of internal programs $\left(\mathrm{X}_{4}\right)$. This means that interpersonal communication that develops in the institution has a significant influence on the effectiveness of international programs.

3. There is a direct influence on doctor competence $\left(\mathrm{X}_{1}\right)$ and interpersonal communication $\left(\mathrm{X}_{2}\right)$ on the effectiveness of internal programs $\left(\mathrm{X}_{4}\right)$. This means that doctor competence and high job satisfaction have a significant influence on the effectiveness of the internship program.

4. There is a direct influence on doctor competence $\left(\mathrm{X}_{1}\right)$ on job satisfaction $\left(\mathrm{X}_{3}\right)$. It means that the competence of doctors has a significant influence on job satisfaction.

5. There is a direct influence of interpersonal communication $\left(\mathrm{X}_{2}\right)$ on job satisfaction $\left(\mathrm{X}_{3}\right)$. It means that high interpersonal communication has a significant influence on job satisfaction.

6. There is a direct influence on doctor competence $\left(\mathrm{X}_{1}\right)$ and interpersonal communication $\left(\mathrm{X}_{2}\right)$ on job satisfaction $\left(\mathrm{X}_{3}\right)$. This means that the doctor's competence and high interpersonal communication at the institution have a significant influence on job satisfaction.

7. There is a direct effect of job satisfaction $\left(\mathrm{X}_{3}\right)$ on the effectiveness of internal programs $\left(\mathrm{X}_{4}\right)$. Means that job satisfaction has a significant influence on the effectiveness of the internship program.

8. There is an influence of doctor competence $\left(\mathrm{X}_{1}\right)$ on the effectiveness of the internship program $\left(\mathrm{X}_{4}\right)$ through job satisfaction $\left(\mathrm{X}_{3}\right)$ Means the competency of the doctor provides a significant influence on the effectiveness of the internship program through job satisfaction.

9. There is an influence of interpersonal communication $\left(\mathrm{X}_{2}\right)$ on the effectiveness of internal programs $\left(\mathrm{X}_{4}\right)$ through job satisfaction $\left(\mathrm{X}_{3}\right)$, It means that high interpersonal communication has a significant influence on the effectiveness of internal programs through job satisfaction.

10. There is a direct influence on doctor competence $\left(\mathrm{X}_{1}\right)$, interpersonal communication $\left(\mathrm{X}_{2}\right)$ and job satisfaction $\left(\mathrm{X}_{3}\right)$ on the effectiveness of internal programs $\left(\mathrm{X}_{4}\right)$. It means that doctor competence, interpersonal communication and job satisfaction have a significant influence on employee satisfaction.

\section{REFERRENCE}

1. Badan Litbang kesehatan Kementerian Kesehatan RI. (2016). Hasil survey dan kesimpulan assessment.

https://www.pusat2.litbang.kemkes.go.id/wpcontent/uploads/2018/04/Laporan-Tahun-

2016_edittri.pdf. Accessed on 22 July 2019.

2. Rasmin, K. (2010). Fusion of Fingerprint and RFID for Authentication System (Doctoral dissertation, Universiti Tun Hussein Onn Malaysia).

3. Interview with interns' doctor in April 2019.

4. Pasolong, H. (2007). Teori Administrasi Publik. Bandung: Alfabeta, 3.

5. Pasalong, H. (2007). Teori Administrasi Kesejahteraan.

6. Pabundu, T. (2008). Budaya Organisasi dan Peningkatan Kinerja Perusahaan, Jakarta: Bumi Aksara, 129.

7. Dubai Ministry of Health. (2011). Medical Internsip Program in Ministry of Health Facilities.

http://www.moh.gov.ae/.../Guideline\%20for\%20 
Medical\%20Int

ernship\%20Program.pdf.

Accessed on 13 Febuari 2018.

8. Undang-undang Republik Indonesia Nomor 29

Tahun 2004 tentang Praktik Kedokteran.

9. Ministry of Health affairs, (2010).

10. Kementerian Kesehatan RI. (2013). Pedoman

Pelaksanaan Program Internsip Dokter Indonesia Buku 2. Edisi 2. Jakarta: Kementrian Kesehatan RI.

11. Department of Continuous Medical Education of Ministry of Health Dubai, (2011).

12. Effendy, O. U. (2007). Komunikasi, Teori dan Praktek, printed $21^{\text {st }}$, Bandung: Rosda Karya, 178.

13. Muhammad, A. (2015). Komunikasi Organisasi, Cet. Ke-14, Jakarta: Bumi Aksara, 66.

14. Blum, M. L., \& Naylor, J. C. (2013). Industrial Psychology: its Theorical and social Fondation. (New York: Harper and Row Publisher, 6.

15. Stephen, R., \& Timothy, A. J. (2009). Perilaku Organisasi organizational behavior, Bandung, Salemba empat, 107.

16. Veithzal, R., \& Deddy, M. (2009). Kepemimpinan dan Prilaku Organisasi, Jakarta: Rajawali Pers, 246.

17. Colquitt, J. A., Lepine, J. A., \& Wesson, M. J. (2009). Organizational Behaviour Improving Performance and Commitment in the Workplace, New York: McGraw-Hill, Inc, 105.
18. Wegner, J. A., \& Hollenbeck, J. R. (2010). Organizational. Behaviour Securing Competitive Advantege, New York: Routledge, 123.

19. Creswell, J. W. (2012). Educational Research, Planning, Conducting, and Evaluating Quantitative and Qualitative Research, Fourth Edition, New York: Pearson, 376.

20. Sugiyono. (2016). Statistika Untuk Penelitian, 23.

21. Miller, J. M. (Ed.). (1991). Archaeological survey of the Kerak Plateau: conducted during 1978-1982 under the direction of J. Maxwell Miller and Jack M. Pinkerton. Scholars Press.

22. Ditto, P. H., \& Lopez, D. F. (1992). Motivated skepticism: Use of differential decision criteria for preferred and nonpreferred conclusions. Journal of Personality and Social Psychology, 63(4), 568.

23. Nafisah, D., \& Raharjo, T. S. (2005). Analisis Pengaruh Gaya Kepemimpinan Terhadap Kepuasan Kerja, Komitmen Organisasi dan Kinerja Karyawan. Skripsi Managemen, Fakultas Ekonomi Universitas Diponegoro.

24. Rivandi, B., \& Moosavizadeh, S. M. A. (2015). Larger benthic foraminifera from the Paleocene sediments in the Chehel-Kaman Formation, north-eastern Iran. Open Journal of Geology, 5(04), 224. 